\title{
Effect of Elephantopus Scaber Linn. leaf extract on mouse immune system
}

\author{
Yufri Aldi*, Megaraswita, Dwisari Dillasamola \\ Department of Pharmacology, Faculty of Pharmacy, Andalas University, Padang, Indonesia \\ *For correspondence:Email:yufrialdi@phar.unand.ac.id; Tel: +62 85274558508
}

Sent for review: 18April 2019

Revised accepted: 20September 2019

\begin{abstract}
Purpose:To investigate the effect of Elephantopus Scaber Linn. ethanol extract on mouse immune system based on macrophage phagocytic activity and capacity, total leukocyte count, and distribution of each type of leukocyte.

Methods: Twenty male mice were randomly assigned to four groups. Group I (control) received sodium carboxy methyl cellulose (Na-CMC), $0.5 \%$ ). Groups II, III, and IV were dosed orally with 10, 30, and $100 \mathrm{mg} / \mathrm{kg}$ ethanol E. scaber leaf extract, respectively, for 7 consecutive days. On the 8th day, a suspension of Staphylococcus aureus was injected intraperitoneally, and macrophage activity and capacity as well as leukocyte count were then measured using a counting chamber device (hemocytometer) and a 400 x microscope.

Results: The effect of the leaf extract at doses of 10,30, and $100 \mathrm{mg} / \mathrm{kg}$ was increase in macrophage activity by 46.25, 54, and $65 \%$, and macrophage capacity by 95.8, 105.4 and 125.8 cell/100 macrophage, respectively; total leukocyte count was 10790, 12360, and 15230 cells/ $\mu$ l, respectively, and lymphocyte was 34.4, 34.6, and $36 \%$. Thus, the leaf extract significantly increased macrophage activity and capacity, as well as segmented neutrophils, and mice total leukocyte counts $(p<0.05)$.

Conclusion: Ethanol extract of E scaber leaf extract increases macrophage activity and capacity, as well as total leukocyte count in mouse; therefore, this extract may provide a highly effective approach for boosting immunity.
\end{abstract}

Keywords: Leukocytes, Macrophages, Phagocytosis, Elephantopus Scaber Linn

\begin{abstract}
This is an Open Access article that uses a fund-ing model which does not charge readers or their institutions for access and distributed under the terms of the Creative Commons Attribution License (http://creativecommons.org/licenses/by/4.0) and the Budapest Open Access Initiative (http://www.budapestopenaccessinitiative.org/read), which permit unrestricted use, distribution, and reproduction in any medium, provided the original work is properly credited.
\end{abstract}

Tropical Journal of Pharmaceutical Researchis indexedby Science Citation Index (SciSearch), Scopus, International Pharmaceutical Abstract, Chemical Abstracts, Embase, Index Copernicus, EBSCO, African Index Medicus, JournalSeek, Journal Citation Reports/Science Edition, Directory of Open Access Journals (DOAJ), African Journal Online, Bioline International, Open-J-Gate and Pharmacy Abstracts

\section{INTRODUCTION}

The immune system provides the body's defense mechanism against foreign entities such as bacteria, viruses, fungi, parasites, and protozoa. It can be divided into specific (acquired) and nonspecific (natural) immunity. The specific immune system provides better protection against antigens, whereas the nonspecific immune system responds more quickly and acts as a frontline defense in dealing with microbes, providing a direct response. The components of the non-specific immune system are phagocytic cells, natural killer (NK) cells, mast cells, and eosinophils. One phagocyte that plays an important role in the immune system is a type of white blood cell (leukocytes) referred to as a monocyte. Monocytes in blood circulation 
differentiate into macrophages when they migrate into bodily tissues. Macrophages play a role in non-specific immunity through the action of microbial phagocytosis and cytokine production that in turn, activates inflammatory mediators [1-4].

The defense mechanism against microorganism attack can be increased by immunostimulant compounds, which are often traditional plantbased medicines. One of these compounds is Elephantopus scaber Linn. from the family Asteraceae, referred to as "tapak liman" in Indonesia. This plant is a wild shrub commonly found throughout the tropics and has been used as a diuretic, antioxidant, antibacterial, antihepatotoxic, and antipyretic. Hence, it could be used as a kidney stone tonic and a treatment for intestinal worms and hepatitis $[5,6]$.

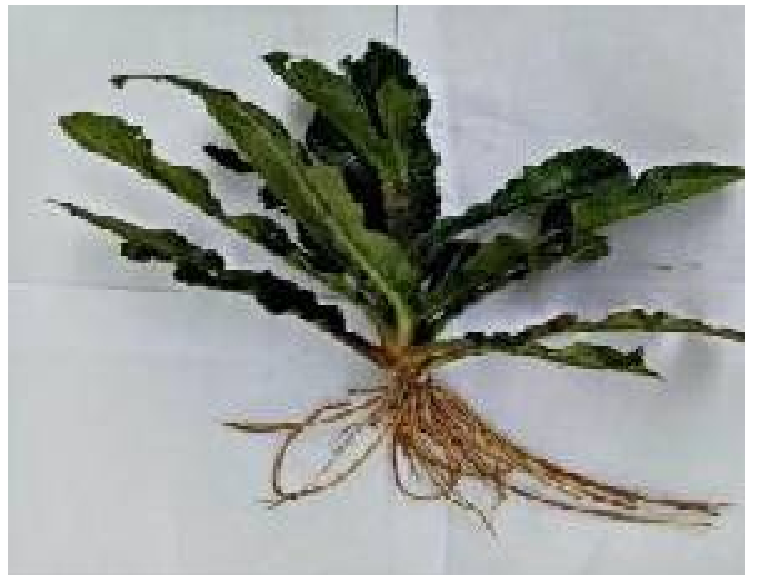

Figure 1: An E. scaber L. plant showing the size of the leaves

Chemical compounds with potential antitumor, antioxidant, or antihepatotoxic properties that have been identified in $E$. scaber $L$. include deoxyelephantopin, flavonoids, scabertopin, isoscabertopin, isodeoxyelephantopin, and 11,13-dihydrodeoxyelephantopin [6-11]. Therefore, the present study was performed to demonstrate the effect of Elephantopus scaber Linn in terms of increasing macrophage phagocytic activity and capacity, total leukocyte count, and distribution of each type of leukocyte.

\section{EXPERIMENTAL}

\section{Materials}

Elephantopus scaber Linn leaves were collected from Limau Manis Region of Padang, Indonesia. The leaves had previously been identified at the Herbarium Universitas Andalas as 474/KID/ANDA/XII/2017 and have the Taxonomic Serial Number: 780294 according to the
Integrated Taxonomic Information System [12]. This study was conducted from July to September 2018 at the Research Laboratory of Immunology and Serology, Faculty of Pharmacy, Universitas Andalas, Indonesia.

\section{Extraction method}

Five $\mathrm{kg}$ of Elephantopus Scaber Linn leaves were chopped to a small size $(0.5-1 \mathrm{~cm})$, dried, and then ground to a fine powder. The powder was macerated in $70 \%$ ethanol $(1: 10)$, stirred occasionally over the first $6 \mathrm{~h}$, and the suspension was allowed to settle for $18 \mathrm{~h}$. The mixture was then filtered three times using no. 40 paper. The filtrate was then reduced with a rotary evaporator until a thick extract was obtained [13].

\section{Characterization of plant extract}

Characteristics of the extract were determined by organoleptic examination, TLC profile, moisture loss after drying, and total ash content. Phytochemical tests were performedtodetermine the presence of alkaloids, flavonoids, saponins, terpenoids, and steroids [14].

\section{Preparation of extract suspension}

An extract suspension was prepared using $\mathrm{Na}$ CMC $(0.5 \%)$. Fifty $\mathrm{mg}$ of $\mathrm{Na}-\mathrm{CMC}$ was added to $2 \mathrm{ml}$ of hot water, left for 10 minutes, and then stirred; $100 \mathrm{mg}$ of Elephantopus Scaber Linn extract was added, and the solution was then stirred. Finally, $9 \mathrm{ml}$ of Aquades was added.

\section{Preparation of Staphylococcus aureus culture}

A culture of Staphylococcus aureus (SA) grown in nutrient agar and nutrient broth was centrifuged at $5000 \mathrm{rpm}$ for $15 \mathrm{~min}$ to form pellets, which were then suspended in $0.9 \%$ saline to form a 0.5 McFarland standard equivalent [15].

\section{Ethical clearance}

All animal housing and experiments were approved the Ethical Committee of the Faculty of Medicine Universitas Andalas (approval ref. no. 029/KEP/FK/2018) [16]. The research complies with the year 2000 revision of the Declaration of Helsinki 1975 [17].

\section{Treatment of mice}

Twenty male mice were randomly assigned to four groups. Group I (control) were treated with $0.5 \% \mathrm{Na}-\mathrm{CMC}$. Groups II, III, and IV were treated 
with 10,30 , and $100 \mathrm{mg} / \mathrm{kg}$ of the ethanol extract, respectively. This ethanol extract was administered orally for 7 consecutive days.

\section{Assessment of macrophage activity and capacity}

On the 8th day, all the mice were injected intraperitoneally with $0.5 \mathrm{~mL}$ of Staphylococcus aureus in $0.9 \%$ physiological saline and left for 1 $h$, then sacrificed and dissected. The peritoneal fluid was taken from the mice and smeared onto a microscope slide. Methanol was added to the slide, then $5 \mathrm{~min}$ later, it was stained with Giemsa for $20 \mathrm{~min}$ then washed with distilled water. An ocular microscope at 1000x magnification was used to observe phagocytic activity and macrophage capacity. Phagocytic activity was measured as the percentage of macrophages that were performing phagocytosis. Macrophage capacity was measured as the number of Staphylococcus aureus cells that were ingested by 50 active phagocyte cells [15].

\section{Evaluation of distribution of leukocyte types in mouse blood}

Blood from the newly sacrificed mice was smeared onto a microscope slide and left to dry. Methanol was added and left for 5 min (fixation), stained with Giemsa for $20 \mathrm{~min}$, and then washed with distilled water. After drying, immersion oil was added, and an ocular microscope at 1000x magnification was used to calculate the number of eosinophil cells, banded neutrophils, segmented neutrophils, lymphocytes, and monocytes [15].

\section{Determination of total leukocyte count}

A leukocyte pipette was filled with mouse blood to the 0.5 mark, topped up to the 11 mark with Turk's solution, and then shaken for $3 \mathrm{~min}$. One to two drops were placed in a hemocytometer and left for 2 min for the leukocytes to settle. The number of leukocytes was calculated in all four count chambers [18].

\section{Statistical analysis}

One-way ANOVA analysis and a Duncan Multiple Range Test (DMRT) were used to analyze differences between samples with the aid of IBM SPSS version 24. $P<0.05$ was set as statically significant.

\section{RESULTS}

The extract obtained from $1.07 \mathrm{~kg}$ of leaves was $35.3 \mathrm{~g}$ (i.e., $3.3 \%$ yield). It was a blackish-brown, odorless, and tasteless. These properties and yield are in agreement with those reported previously in "Farmakope Herbal Indonesia" [13].

A TLC profile for the ethanolic extract was run using a mobile phase of ethyl acetate: n-hexane: methanol in a volume ratio 5:5:1, and a stationary phase of silica gel F254 with a Liebermann-Burchard stain. One of the bands had a similar $\mathrm{Rf}$ to deoxyelephantopin (0.68) indicating its presence in the extract.

Shrinkage on drying was $8.6 \%$, and total ash content was $2.6 \%$. Phytochemical analysis indicated the presence of flavonoids, saponins, phenolics, and steroid and triterpenoid compounds.

The phagocytic activity and capacity of the mouse macrophages increased in proportion to the extract dose (Figures 2 and 3). A one-way ANOVA demonstrated a significant increase in both peritoneal macrophage activity and capacity with $E$. scaber L. extract dosage $(p<0.05)$.

The leukocyte cells counted were eosinophils, segmented neutrophil cells, lymphocytes, and monocyte neutrophil cells. The forms of these leukocytes in the mice can be seen in Figure 5.

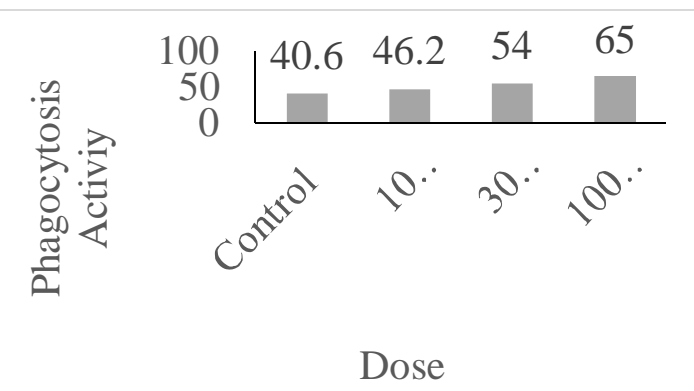

Figure 2: Relationship between phagocytosis activity of macrophage cells and E. scaber L. ethanolic extract dose

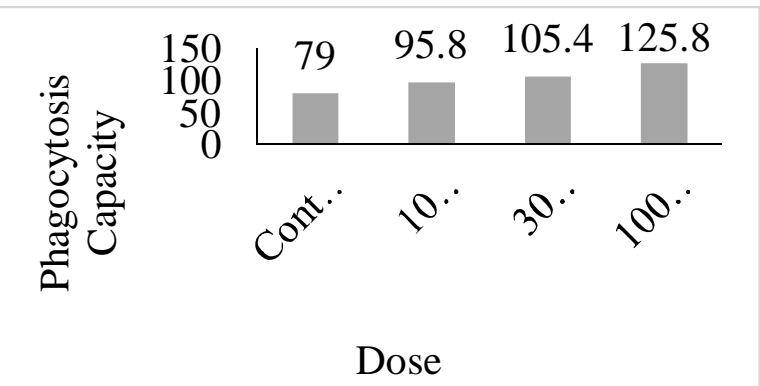

Figure 3: Relationship between macrophage phagocytosis capacity and E. scaber L. ethanol extract dose 


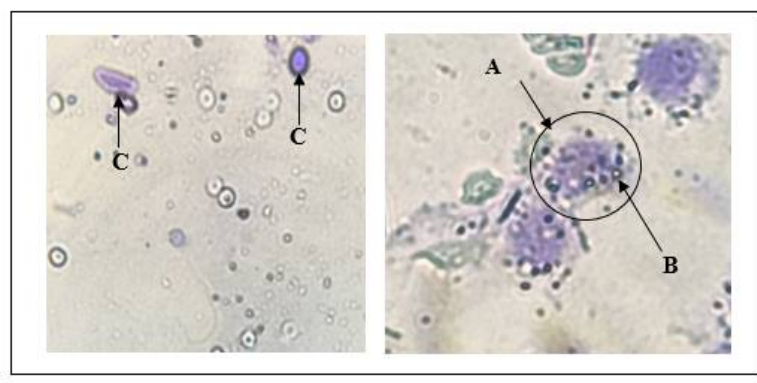

Figure 4: Phagocytosis of SA bacteria by macrophages. $\mathrm{A}=$ Active macrophage, $\mathrm{B}=$ Staphylococus aerus (SA), C = Macrophage

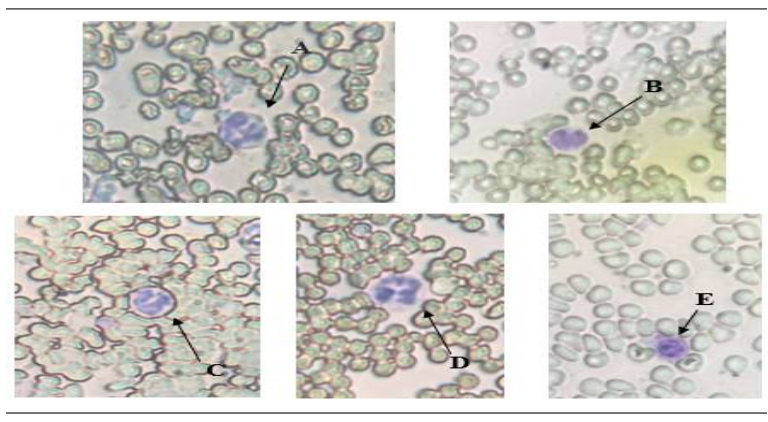

Figure 5: Types of leucocytes in the mice. $\mathrm{A}=$ Segmented neutrophil cells; $\mathrm{B}=$ Monocytes; $\mathrm{C}=$ Banded neutrophil cells; $\mathrm{D}=$ Eosinophils; $\mathrm{E}=$ Lymphocytes

Most leucocytes observed were neutrophil and lymphocytes, with eosinophils being the least observed (Figure 6). Because monocytes had differentiated into macrophages, the number of monocytes was small. Basophils could not be observed because they were dissolved in Giemsa. One-way ANOVA testing indicated that the proportion of segmented neutrophil and monocyte cells were significantly different for each dosage level $(p<0.05)$.

\begin{tabular}{|c|c|c|}
\hline & $50^{2056}$ & $34.4^{36} 34.6$ \\
\hline 迹nented & $\mathrm{C}$ & 9.4 \\
\hline Feutrophils & & ${ }_{6.8}^{9.2} 11$ \\
\hline Baded Neutrophil & & $20.4^{32}$ \\
\hline 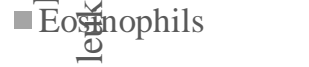 & & 8.4 \\
\hline Lymphocytes & & 8.4 Dose \\
\hline
\end{tabular}

Figure 6: Relationship between leucocytes cell types in mice and E.scaber L. ethanol extract dose

The total leukocyte count increased significantly with an increase in extract dose $(p<0.05)$, as seen in Figure 8, indicating immune response strengthening [1].

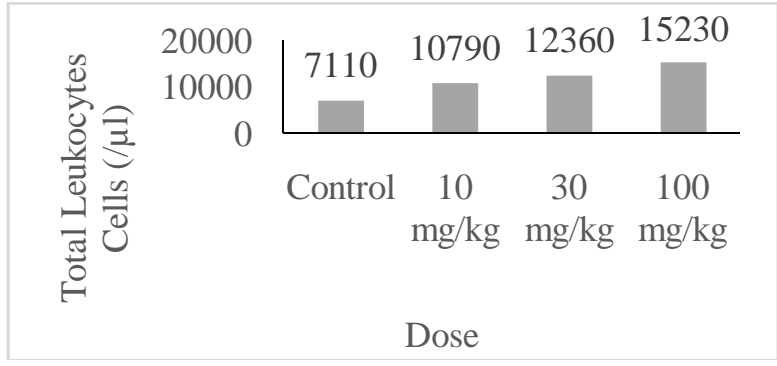

Figure 7: Relationship between total leukocyte count in mice and $E$. scaber L. ethanol extract dose

\section{DISCUSSION}

According to the "Farmakope Herbal Indonesia", E. scaber L. extract is a blackish-brown color, odorless, and has a bitter taste. It is also stated that the drying shrinkage of the treadmill must be $<10 \%$ and the total ash content is $<5 \%$ [13]. These demands were achieved by the extract obtained from $E$. Scraber $L$. in this research.

One content of $E$. scaber L. leaf extract is flavonoids, with $<6.2 \%$ in quercetin form [13]. The flavonoids of $E$. scaber L. may have antibacterial properties that improve the phagocytosis activity and capacity of macrophage cells [19]. Phagocytic macrophage cells can be seen in Figure 4.

The increase in macrophage activity and phagocytic capacity is most likely due to release of cytokines by phagocytic cells that is induced by bioactive compounds in the extract of $E$. scaber L. The cytokine compounds that can increase the activity and capacity of macrophage cells are IL-1 (Interleukin-1), IL-3 (Interleukin-3), and IL-10 (Interleukin-10). These cytokines are produced by mononuclear phagocytes such as monocyte and macrophage cells. When bacteria are present in the blood circulation, the first cellular immune response is from phagocytic cells such as macrophages, neutrophils, eosinophils, and monocytes in the blood. Macrophage cells are effective phagocytic cells that ingest foreign substances and transfer them into endosomes where they can be destroyed by lysozymes and other peroxide-generating compounds. Protein fragments derived from antigens are bounded by the major histocompatibility complex (MHC) that is carried to the surface of macrophage cells. Furthermore, these fragments are also presented to $T$ lymphocytes cells so that these cells become active. These activated T lymphocyte cells then release other cytokines, such as IL-1, IL-6, IL-8m IL12, and TNF-alpha [20]. 
The IL-1 receptor is found in macrophage cells and endothelial surfaces. If this receptor is occupied by IL-1, the cell will then produce IL-6. These IL- 6 cells have receptors in B cells so that the production of antibodies increases. With the increase in antibodies, the body's protection against infection subsequently increases.

The bioactive compounds contained in the extract appear to be able to increase IL-1 production. Hence, they trigger an increase in phagocytic activity, allowing a higher percentage of macrophage cells to engulf the SA bacteria. This increase in IL-1 also increases phagocytic capacity, increasing the number of SA cells that can be engulfed by each macrophage cells, as shown in Figure 4. The release of IL-1, IL-6, and IL-8 produced by activated T lymphocyte cells increase the hematopoiesis process, resulting in an increased leukocyte count (as shown in Figure 7).The compounds contained in E. scaber L. can also increase leukocyte cell total counts, as shown in Figure 7. This increase is a result of higher production of $\mathrm{IL}-1$, which binds to myeloblast cells that then proliferate and differentiate into neutrophil cells, eosinophils, and cell basophils. Normally in mice, the number of neutrophil segments $=16.4 \%$; rod neutrophils $=$ $22.8 \%$; eosinophils $=8.4 \%$; $32 \%$ lymphocytes; and monocytes $20.4 \%$. Figure 6 shows that only lymphocyte cells increased in number. These cells are responsible for the humoral and cellular immune responses.

Lymphocyte cells differentiate to form B cells, T cells, and Natural Killer cells (NK cells). Natural killer cells are the main component responsible for preventing infections from viruses and bacteria [1].The compounds contained in $E$. scaber L. leaves not only increased the activity and phagocytosis of macrophage cells, but also increased the total number of leukocyte cells, particularly lymphocytes. Thus, Tapak Liman leaves may improve the body's resistance to viruses and bacteria.

\section{Limitations of the study}

This study investigated the initial response of the immune system of male white mice to E. scaber L. ethanol leaf extracts. The longer-term effects on immune system, the effects on other mammals, and the optimal dose require further research.

\section{CONCLUSION}

The ethanol extract of $E$. scaber L. leaves increases the body's resistance to microorganisms that cause infection through increased macrophage activity and capacity in mice, as well as elevates the total number of leukocyte cells. Therefore, the extract has the potential to be developed for boosting the immune system in humans.

\section{DECLARATIONS}

\section{Acknowledgement}

The authors would like to express special appreciation to the Rector of Universitas Andalas and the Institute for Research and Community Service (Lembaga Penelitian dan Pengabdian Masyarakat"LPPM") Universitas Andalas for financial support in the form of a Professor Research Grant of Universitas Andalas.

\section{Conflict of interest}

No conflict of interest is associated with this work.

\section{Contribution of authors}

We declare that this work was done by the authors named in this article and all liabilities pertaining to claims relating to the content of this article will be borne by the authors.

\section{Open Access}

This is an Open Access article that uses a funding model which does not charge readers or their institutions for access and distributed under the terms of the Creative Commons Attribution License (http://creativecommons.org/licenses/by/ 4.0) and the Budapest Open Access Initiative (http://www.budapestopenaccessinitiative.org/rea d), which permit unrestricted use, distribution, and reproduction in any medium, provided the original work is properly credited.

\section{REFERENCES}

1. Abbas AK, Lichtman AH, Pillai S. Cellular and Molecular Immunology: ed 8. Philadelphia: Elsevier-Saunders; 2015; pp 51-86.

2. Bratawidjaja KG, Rengganis I. Basic Immunology, ed 9, Agency Publisher of the Faculty of Medicine, University of Indonesia, Jakarta; 2010. 27-56 p.

3. Radji M. Immunology and Virology, Revised Edition. ISFI Publishing, Jakarta; 2015. 22-64 p.

4. Coligan JE. Current Protocol in Immunology, Supplement 1. Baltimore: John Wiley \& Sons Inc; 2010.

5. Hammer MLA, Emily AJ. Tapping an Amazonian plethora: four medicine plants of Marajo Island, para (Brazil). J Ethnopharmacol 1993; 40(1): 53-75. 
6. Sheeba KO, Pallara JW, Bhaskara KL, Mukael SL. Antioxidant and antihepatotoxic efficacy of a methanolic extract of Elephantopus scaber Linn in Wistar rats. Asian Pac Trop Dis 2012; s904-s908.

7. Silva $L B D$, Herath $W H M$, Jennings $R C$, Mahendra $M$, Wannigama GE. A New sesquiterpene lactone from Elephantopus scaber. J Phytochem. 1982; 21(5): 11731175.

8. Paul PHB, Hon PM, Cao H, Dominic CTW, Wu BM, Mak TCW, Chie CT. Sesquiterpene lactones from Elephantopus scaber. J Phytochem. 1997; 44(1): 113116.

9. Indonesia National Agency of Drug and Food Control "Badan Pengawas Obat dan Makanan Obat Republik Indonesia (BPOM RI)". A monographic medicinal plant extracts in Indonesia, Volume 1. Jakarta: BPOM RI; 2004.

10. Xu G, Liang Q, Gong Z, Yu W, He S, Xi L., Antitumor Activities of the four Sesquiterpene Lactones from Elephantopus scaber L. Exp Oncol. 2006: 28(2); 106107.

11. Geetha BS, Nair MS, Latha PG, Remani $P$. Sesquiterpene lactones isolated from Elephantopus scaber L. inhibits human lymphocyte proliferation and the growth of tumor cell lines and induce apoptosis in vitro. J Biomed Biotechnol. 2012; 10: 1-8.

12. Integrated Taxonomic Information System, [Cited 2019 Mar 25]. Available from: https://www.itis.gov/servlet/
SingleRpt/SingleRpt?search_topic=TSN\&search_value= 780294\#null

13. Republic of Indonesia Ministry of Health. Indonesian Herbal Pharmacopoeia, ed 1. Jakarta; 2008.

14. Republic of Indonesia Ministry of Health, General Standard Parameters of Medicinal Plant Extracts in Indonesia, Ed 1. Jakarta: Directorate General of Drug and Food Control; 2000.

15. Aldi Y, Purnamasari R, Dillasamola D, Friardi. Test immunomodulatory effects of ethanol extract skin of purple sweet potato (Ipomoea batatas (L.) Lam) with carbon clearance method and the number of leukocytes. Res J Pharm Biol Chem Sci. 2016 1; 7(3): 1192-200.

16. Ethical Committee of Faculty of Medicine Universitas Andalas. Ethical Clearance. 2018.

17. World Medical Association. "World Medical Association Declaration of Helsinki. Ethical principles for medical research involving human subjects." Bulletin of the World Health Organization 79.4 (2001): 373.

18. Hansen PJ. Laboratory procedures use of Hemacytometer. Florida: University of Florida; 2000.

19. Anitha WT, Marimuthu J, Jeeva S. Anti-bacterial studies on Hemigraphis colorata (Blume) H.G Hallier and Elephantopus scaber L. Asian Pacif J Trop Med. 2012; 52-57.

20. Burtis CA, Ashwood ER, Bruns DE. Tietz textbook of clinical chemistry and molecular diagnostics-e-book. Elsevier Health Sciences; 2012. 